\title{
EDUCAÇÃO AMBIENTAL ENTRE PRÁTICAS CULTURAIS COTIDIANAS DOS MASCARADOS DO CONGO
}

\author{
Andreia Teixeira Ramos ${ }^{\mathrm{i}}$ \\ Martha Tristão Ferreira ${ }^{\text {ii }}$
}

\begin{abstract}
Resumo
A pesquisa objetivou cartografar e problematizar saberesfazeres socioambientais entre artes de fazer e narrar a produção dos Mascarados do Congo, como prática cultural secular. A metodologia se aproxima das pesquisas em Educação Ambiental (EA), cartográfica e dos estudos com os cotidianos. Apostamos na EA autopoiética, como invenção de si e do mundo, e que emergem entre conflitos e coletividades com as redes de conversações dos sujeitos praticantes, potencializando dimensões políticas, éticas e estéticas, entre processos, fluxos, tensões e conversas, envolvendo professores/as, estudantes e congueiros/as.
\end{abstract}

Palavras-chave: Educação Ambiental Autopoiética; Práticas Culturais cotidianas; Mascarados do Congo.

\section{ENVIRONMENTAL EDUCATION AND THE EVERYDAY CULTURAL PRACTICES OF MASCARADOS DO CONGO}

\begin{abstract}
This research aimed to map and discuss social and environmental activities and knowlegde in the art of making and narrating the production of Mascarados do Congo, a secular cultural practice. The methodology is based on research in Environmental Education (EE), cartography and studies of everyday life. We invested in autopoietic EE, as invention of the self and the world, and emerging conflicts between communities and community with networks conversations of dwellers, enhancing political, ethical and aesthetic dimensions, between processes, flows, tensions and conversations involving teachers, students and congo practitioners.
\end{abstract}

Keywords: Autopoietic Environmental Education; Everyday cultural practices; Mascarados do Congo. 
Por isso eu pergunto a você no mundo se é mais inteligente o livro ou a sabedoria, o mundo é uma escola, a vida é um circo, amor, palavra que liberta já dizia o profeta. Gentileza, (MONTE, 2000).

Com inspirações nas palavras de Marisa Monte "O mundo é uma escola", escrevemos este artigo, fragmento de uma pesquisa de Mestrado do Programa de Pós-Graduação em Educação da Universidade Federal do Espírito Santo, defendida em 2013, tendo como agência de fomento a CAPES ${ }^{\text {iii }}$. O tex to convida ao encontro e deslocamentos com movimentos da Educação Ambiental com inspirações na pesquisa cartográfica com os procedimentos das conversas tecidas nas redes cotidianas do campo problemático habitado pela pesquisa. $\mathrm{O}$ objetivo foi cartografar e

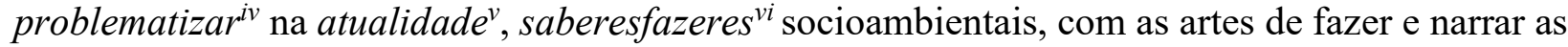
práticas culturais cotidianas dos mascarados do congo, e, os atravessamentos com as redes cotidianas escolares e outros espaços de convivência da região da pesquisa.

Nesse campo problemático, apostamos na Educação Ambiental autopoiética vii (MATURANA, 1999 e 2006), que acontece na invenção de si e do mundo com a produção dos mascarados. Nossa intenção foi pensar essa perspectiva com os estudos de Humberto Maturana, "desmascarando" pistas e experiências humanas e coletivas no linguajear, potencializando as dimensões ontológica, ética e estética dos movimentos de conversar e sustentabilizar enquanto ação.

Nosso desejo foi acompanhar os processos da produção dos mascarados como personagem secular de um município localizado numa comunidade rural, na região metropolitana de um Estado do sudeste do Brasil, por meio dos fluxos, encontros, narrativas, conversas, linhas, formas, forças, "entrando nas travessias e deixando-nos atravessar por elas" (CARVALHO, 2011).

O campo problemático desta pesquisa, está inserido no contexto sociocultural marcado pelo hibridismo entre indígenas, negros ${ }^{\text {viii }} \mathrm{e}$ imigrantes europeus. No passado, o município de Cariacica era desprovido de unidades de conservação, atualmente, foram criadas Áreas de Preservação Ambiental (APA) com iniciativas de Educação Ambiental enredadas com as práticas culturais cotidianas locais.

A pesquisa faz um zoom com atenção maior no personagem singular e ilustre do congo da região. Nas travessias com os movimentos metodológicos, os objetivos passeiam pela produção de conhecimento numa posição ética, estética e política; desejando dialogar com as práticas 
culturais cotidianas locais, entrelaçadas com o campo da Educação Ambiental autopoiética, ressaltando potencialidades ambientais locais e modos de sustentabilizar relações com o ambiente natural.

Nesse sentido, que singularidades atribuir à Educação Ambiental? Quais interlocuções emergem desse campo com as práticas culturais? Quais as potências da Educação Ambiental autopoiética em problematizar discursos que escamotearam singularidades das práticas culturais na região pesquisada? Como entender os mascarados diante das identidades híbridas e descentradas na atualidade?

É claro que não temos a pretensão, nem de longe, de tentar resolver-responder todas essas questões. São inquietudes que suscitam problematizações e nos estimularam modestamente percorrer com as travessias da pesquisa. Para alinhavar a composição do artigo, inserimos algumas imagens que foram capturadas pela autora do artigo durante a pesquisa. Imagens para ventilar e deslocar os pensamentos.

\section{Travessias metodológicas}

A pesquisa percorre travessias inspiradas nos trabalhos de Alves (2010), Carvalho (2011), Certeau (2008a, 2008b), Deleuze (1992), Ferraço (2003), Kastrup (2009), Passos et al. (2010), Maturana (1999; 2002 e 2006) Tristão (2013), criando encontros, desencontros, reencontros rizomáticos, um fio puxando o outro, e como dizia Deleuze (1992), cada um, como um todo já é muitos... sempre se trabalha em vários.

As pesquisas em Educação Ambiental (TRISTÃO, 2013) enredada com a pesquisa cartográfica (KASTRUP, 2007; PASSOS et al, 2010) e com os cotidianos (ALVES, 2010; FERRAÇO, 2003), pressupõem o acompanhamento de percursos, conexão de redes e rizomas com as práticas culturais cotidianas da produção dos mascarados do congo, produzida numa comunidade rural em uma região do sudeste do Brasil.

Nesse sentido, a inspiração na cartografia surge como princípio de rizoma, são múltiplas as entradas em uma cartografia, é como mapa móvel, numa rede de conexões e experiências. Faça rizoma, não faça raiz, nunca plante! Não semeie, pique! Não seja nem uno nem múltiplo, seja multiplicidades! Faça a linha e nunca um ponto! A velocidade transforma o ponto em linha! Seja rápido, mesmo parado! Linha de chance, jogo de cintura, linha de fuga. Nuca suscite um General em você! Faça mapas. (DELEUZE e GUATTARI, 2011, p.48). 
Os sujeitos colaboradores desta pesquisa foram: educadores/as e educandos de redes cotidianas escolares, mestres de congo, artesão de congo, congueiras, filhos e filhas dos congueiros, que compõem a Associação de banda de congo de Taquaruçú. A geografia da pesquisa está entre uma a Reserva Biológica Estadual de Duas Bocas e uma APA Municipal do Moxuara, a uma altitude aproximada de 500 metros, coberto pela Mata Atlântica.

A produção de dados com os sujeitos praticantes ${ }^{i x}$ (CERTEAU, 2008a) da pesquisa, aconteceu no acompanhamento dos fluxos de redes de conversações, tecidas na coletividade ao longo do ano de 2011 e parte de 2012, em encontros quinzenais de compartilhamento de vivências. ${ }^{x}$ Utilizamos o diário de campo, além de fotografias, gravações e transcrições. Com isso, a pesquisa cartográfica introduz o pesquisador num movimento singular de conhecer, agir e habitar experiencias $^{x i}$ (LARROSA, 2004) com os sujeitos praticantes, na tessitura dos fios do campo problemático da pesquisa.

\section{Rastreando os Mascarados do Congo}

A pesquisa se pluralizou com inspirações em Certeau, no que ele denomina de Cultura no Plural (2008b). Nas palavras de Luci Giard, as pluralizações das culturas são verdadeiros ataques às celebrações estabelecidas da "cultura no singular" e que evidenciam o "singular de um meio", assim, a vontade política, centrada na noção de Certeau (2008b) de cultura no plural, propõe a dissolução de hierarquização das culturas.

Como dissolver as repressões políticas e sociais dos discursos que hierarquizam as culturas? Como escapar das concepções estáticas, majoritárias e reducionistas dos discursos que classificam as invenções cotidianas, e que são invenções culturais? Como trazer à tona o poder cultural que se infiltra em qualquer teto, em qualquer espaço, nas redes cotidianas?

Nas brechas, entre o dizer e o fazer, pensamos aqui, as práticas culturais enquanto resistências e antidisciplinas, que são extraídas nos ruídos das maneiras de fazer, das astúcias e táticas dos sujeitos praticantes dos cotidianos. Sempre recordando e nos inspirando em Certeau (2008a), que não devemos tomar o outro como tolo, percebendo as microdiferenças e as microresistências, nos jogos das táticas silenciosas e sutis da vida cotidiana.

$\mathrm{Na}$ busca por publicações que problematizam as questões de investigações aqui levantadas, destacarei algumas, a começar com os livros de Neves (2008). A primeira referência impressa de bandas de congo na região está no livro de Sequeira (1893): 
Notícias a respeito das antigas bandas de congos no século XIX podem ser colhidas, talvez, nos livros dos viajantes estrangeiros que por aqui passaram, nos apontamentos de outros visitantes interessados, ou nos jornais que, na época, circulavam. Quase todas dirão da presença de índios e de negros nas antigas bandas de congos (Apud SANTOS, 2012, p. 76).

Paradoxalmente, a importante coletânea capixaba chamou-nos atenção pela ausência de registros dos ilustres mascarados. No que se refere à produção científica em relação as práticas culturais, percebemos a potência desse campo problemático ainda em constituição, justificada pela pouca expressão de trabalhos publicados num diálogo com a Educação Ambiental.

Encontramos, também, a obra de Mazoco (1986) “O Congo de Máscaras”.

As máscaras, motivo da brincadeira (...). Os mascarados vão chegando de suas casas já trajados e ficam aguardando, ocultos venda (...). Abrindo o cortejo vão os mascarados. Atrás o povo. O cortejo vai num barulho alegre, anunciados pelos fogos, pelo som grave do tambor, pelo ronco da cuíca, pelo trilar do apito, pela algazarra e pelo canto. Ao longo do trajeto já determinado, o cortejo vai parando, sempre acompanhado de fogos atraindo mais gente por vezes recolhendo mais mascarados, que durante o cortejo vão em hilariante festividade, em brincadeiras e estripulias, caindo pelas estradas, correndo em direção às pessoas, cantando e dançando. (MAZOCO, 1986, p. 23-25).

A pesquisa de Freitas (2007), intitulada "O Carnaval de Congo" demonstra que:

É uma manifestação festiva que articula valores do contexto históricos tradicionais marcados por um sentido de religiosidade católica que destaca a Festa da padroeira e manifestações de origem africana relacionadas ao congo. $\mathrm{O}$ acontecimento retrata-se como expressivo onde o congo representa a mais importante marca da cultura popular desse estado. As bandas de congo tornaramse uma forma de representação do passado escravocrata que se projeta na atualidade como expressão da identidade cultural e marca dos movimentos festivos que se tornam espetáculos na sociedade urbano industrial (FREITAS, 2007, p. 01).

Consideramos as identidades como "fragmentadas" e "descentradas", não fixas e em processos de identificação dos sujeitos imersos na diferença do devir cotidiano em redes de saberesfazeres, alargando, ventilando e atualizando, na contemporaneidade, a noção de tradição. A pesquisa de Souza (2005) produziu uma arqueologia sócio histórica das bandas de congo mirim numa escola estadual pluridocente. 
O bairro rural é um lugar encantado em meio a montanhas, matas e nascentes. Abriga segredos e linguagens que somente são revelados em dias como o da padroeira, quando as bandas se reúnem para o Carnaval de Congo, num espetáculo radiante em que cores, sonoridades e danças principiam ciclos de comunal idade mantidos pelas Bandas de Congo de Santa Isabel de Roda d’Água, São Benedito de Piranema, São Benedito de Boa Vista e São Sebastião de Taquaruçu. Essas bandas compõem a Região, e juntas, através dos tempos, as gerações referendam e partilham da africanidade e da magia dos Tambores de Congo, reafirmando e legitimando seus antepassados (SOUZA, 2005, p. 18).

A autora destaca uma das versões em relação aos vestígios do congo de mascarados:

Entre as muitas particularidades dessa região, destacada pelo Carnaval de Congo. Tradição do século XVII, originalmente uma procissão em homenagem à padroeira, na qual máscaras e fantasias ocultavam negros e brancos que não queriam, ou não podiam ser reconhecidos. Trata-se de uma tradição que remonta ao século XVII, quando os trabalhadores escravizados aproveitavam da saída de seus senhores para a festa em homenagem à padroeira Com o passar do tempo, também os brancos que não queriam, ou não podiam ser reconhecidos, se ocultavam atrás de máscaras rústicas de papel e vestiam roupas adornadas com folhas de bananeira (SOUZA, 2005, p. 102).

Nos caminhos ziguezagueantes (Certeau, 2008b) dessa cartografia nos territórios existenciais habitados, afastando-se das clausuras das práticas culturais cotidianas e deixando-nos levar por pistas, apostamos nos cotidianos inventados nas mil maneiras de caças não autorizadas dos sujeitos praticantes do congo dos mascarados. Por que realizam o congo de máscaras? Por que produzem as máscaras? Serão essas maneiras de fazer o congo de máscaras, modos de usos subversivos e de reinvenção das celebrações das comemorações do dia da santa padroeira do Estado?

Portanto, para Certeau (2008b) as artes de fazer e os usos dos produtos culturais, desenham operações multiformes escondidas e que habitam as redes cotidianas, criando artes de combinar indissociáveis às artes de utilizar, como é o caso, da invenção do carnaval de congo de máscaras. Eis os possíveis! Cartografar e problematizar saberesfazeres das artes de fazer e narrar, a produção dos mascarados do congo na atualidade e os atravessamentos com as redes cotidianas de uma escola municipal. Nosso desejo é problematizar os diversos pontos de vista que habitam uma mesma experiência de realidades de práticas culturais, sem deixar-se dominar por possíveis origens desse personagem secular. 
E como dizia Deleuze, em “Conversações” (1992, p. 109),

Não buscaríamos origens mesmo perdidas ou rasuradas, mas pegaríamos as coisas onde elas crescem, pelo meio: rachar as coisas, rachar as palavras. Não buscaríamos o eterno, ainda que fosse a eternidade do tempo, mas a formação do novo, a emergência ou o que Foucault chama de "a atualidade" (DELEUZE, 1992, p. 109).

\section{Saberesfazeres socioambientais na produção dos Mascarados do Congo.}

Nossa aposta em pensar a Educação Ambiental autopoiéticas, são inspirações produzidas com os pensamentos de biólogo chileno Humberto Maturana, que pesquisou o funcionamento dos seres vivos, do sistema nervoso e da cognição. Suas pesquisas, em parceria com Francisco Varela, ficaram conhecidas como a Biologia do Conhecer, ou Autopoiese. Seus enunciados científicos evidenciam que a potência da vida, e principalmente da vida humana, está nas relações éticas entre seres humanos e outras formas de vida, cultivadas no fluir das conversas e no compartilhar das vidas cotidianas em amorosidade.

Produzimos, desde nossos ancestrais, modos de vida como seres amorosos no compartilhar alimentos e cuidados, nos acoplando com as realidades e constituindo aquilo que Maturana denomina de Biologia do Conhecer ou Autopoiese. Autopoiese vem do grego: autós, próprio; poieu, poiein, poiesis, faço, fazer, o feito, é a produção de si mesmo, autofazimento - um sistema autopoiético é uma teia de processos que vão se produzindo através de transformações e interações (ASSMANN, 1998).

Queremos agora colocar à mesa de discussão a Biologia do Conhecer e a Biologia do Amor, ressaltando a potência da emoção do amor e seus entrelaçamentos possíveis com a Educação Ambiental autopoiética, principalmente com o fenômeno biológico das aprendizagens inventivas (KASTRUP, 2009) nas coletividades vivas e não-vivas.

Queremos aqui considerar a relação da Educação Ambiental autopoiética com redes de conversações cotidianas em espaços de convivência, na qual as aprendizagens são produzidas de modo permanente e de maneiras recíprocas, escapando de modelos, fórmulas, controles e indicadores. As vidas escapam! Produzem-se nas relações!

Pensar a autopoiese é pensar em processos de "autofazimentos" de autoprodução de sistemas autopoiéticos. Como nos tornamos o que somos? Nas palavras de Maturana e Varela 
(1997, p. 18), "Somos sistemas autopoiéticos moleculares, e que entre tantos sistemas moleculares diferentes, somos sistemas autopoiéticos".

Entendemos a autopoiese como movimentos rizomáticos, onde os seres vivos constituem os mundos e são constituídos por eles, numa autoprodução, que acontece nas relações cotidianas com conflitos, tensões e negociações, no compartilhar, na solidariedade e apostando na aceitação do outro como legítimo outro junto a nós no conviver amoroso. Educar com conversas? Educar com redes de conversações? E as pedagogias dos silêncios? Educação Ambiental autopoiética? Educações Ambientais autopoiéticas?!

Podemos aqui elaborar algumas relações com as noções da Biologia do Conhecer e da Biologia do Amor, problematizando nessa relação, a noção do conhecer, que emerge nas conversações, no conviver com o outro, diferente daquelas concepções que inibem as condições biológicas e cognitivas do observador. Nessas discussões, as conversações assumem a condição ontológica do ser humano no fluir do emocionar e do linguajar, onde a razão entra, mas não é o elemento fundante.

Ao fluir o nosso emocionar num curso que é o resultado de nossa história de convivência dentro e fora da linguagem, mudamos de domínio de ações, e, portanto muda o curso de nosso linguajar e de nosso raciocinar. A esse fluir entrelaçado de linguajar e emocionar eu chamo conversar, e chamo conversação o fluir, no conversar, em uma rede particular de linguajar e emocionar (MATURANA, 1999, p. 172).

Continuando a conversa com Maturana (1999), o pensador sugere que "conversar" vem do latim, cum - com; e versare - dar voltas com o outro. Como mamíferos, somos animais que nos nossos devires evolutivos aprendemos a coordenar os fluxos emocionais nas ações, como animais linguajantes.

Estou chamando de ações tudo o que fazemos em qualquer domínio operacional que geramos em nosso discurso, por mais abstrato que ele possa parecer. Assim, pensar é agir no domínio do pensar, andar é agir no domínio do andar, refletir é agir no domínio do refletir, (...), e assim por diante, e explicar cientificamente é agir no domínio do explicar científico (MATURANA, 2006, p. 128-129).

Dessa forma, Maturana entende a conversa como um domínio operacional biológico e ontológico dos seres humanos, constituindo cotidianamente, redes de conversações na linguagem: [...] Chamo de conversação nossa operação nesse fluxo entrelaçado de coordenações consensuais de linguajar e emocionar e chamo de conversações as diferentes redes de coordenações entrelaçadas e consensuais de linguajar e emocionar que geramos ao vivermos juntos como seres humanos (MATURANA, 2006, p. 132). 
Assim, podemos pensar a Educação Ambiental autopoiética em redes de conversações? Como exercitamos nossas relações de aceitação e respeito por si e pelos outros imersos na sociedade de controle e de competição? Como os sujeitos praticantes dos mascarados do congo, vivem e são produzidos, em redes de conversações cotidianas?

\section{Feituras dos Mascarados do Congo}

Diversos pontos de vistas dos observadores e sujeitos praticantes da pesquisa, emergiram nas travessias da produção dos mascarados do congo. As redes de conversações que compõe as feituras das máscaras, desenham saberesfazeres socioambientais, tecidos nas coletividades das redes cotidianas que atravessaram a pesquisa. Nesse sentido, destacamos um fio de conversação, transcrita no diário de campo, em que o mascarado é batizado como "João Bananeira".

Mestre de Congo: A história do João Bananeira surgiu na nossa região. É um personagem que faz o carnaval de congo. Antigamente o mascarado era de pano, não tinha máscara como nós fazemos hoje. Era de um pano, fazia os olhinhos, a boquinha aí, pintava aquele pano de preto, aí botava no rosto e ficava na casa de um e outro, depois nós fazíamos as formas de barro da natureza, não era de argila, mas era muito difícil de fazer, era o dia todo para fazer uma forma daquele barro mole, pra criança era muito difícil tinha que fazer e ficar duas horas para colocar o papel e conseguir fazer a máscara. A oficina que eu ensino as crianças agora, eu compro a argila, faço a forma da massa. No dia eu boto o papel, faço a forma, boto o jornal e antes do jornal boto uma sacola de papel aí vai rasgando os papéis vão colocando umas doze ou quinze camadas de papel, para formar a máscara dura oito dias.

Nas palavras do mestre de congo, a duração da produção da máscara necessita de oito dias, período que envolve crianças, adultos, mestres de congo, congueiras, todos em movimentos de compartilhar as artes de fazer seus próprios mascarados, em suas singularidades e subjetividades, inventando a si mesmos, em aprendizagens inventivas, autopoiéticas, e com potencial criador nas coletividades.

Quais singularidades povoam o surgimento dos mascarados do congo? A ética e a estética que envolvem as feituras dos mascarados do congo, são estratégias negociadas por diferentes redes de conversações das comunidades do congo? 
Continuando a conversa, pensar com Maturana é perceber e assumir nossa condição biológica no domínio operacional do pensar! É também assumirmos que nos tornamos humanos no linguajar, na linguagem e nas redes de conversações.

[...] se queremos explicar a linguagem como fenômeno biológico, o que temos que mostrar é de que maneira ela surge, de que modo na história das interações dos seres vivos essa recursão venha a ter lugar. E não só isso: precisamos mostrar também como a linguagem se origina na história dos hominídeos (MATURANA, 2006, p. 73).

Os estudos de Maturana trazem ingredientes potentes para pensarmos as relações da feitura dos mascarados, com a biologia humana e com a linguagem, ao considerar nossas experiências de sermos seres humanos e vivermos numa linguagem, constituída e conservada em relações amorosas e cooperativas no nosso devir evolutivo na história dos primatas bípedes.

$\mathrm{Na}$ evolução - biológica ou cultural -, não há um caminho pré-estabelecido. $\mathrm{O}$ devir evolutivo é uma deriva que segue qualquer direção na qual mantém o viver. A cada instante, o rumo que ele de fato segue é definido pelo que se conserva neste instante em torno da manutenção do viver. Daí resulta que aquilo que continua geração após geração como modo de vida, é o que de fato define uma linhagem biológica ou cultural - e o que determina no que uma ou outra se transforme em seu devir (MATURANA; VERDEN-ZOLLER, 2004, p. 248).

Ao apresentar argumentos que defendem que nossa racionalidade é constituída no emocionar e no linguajar, Maturana (2006) nos faz pensar, que nós humanos, nos constituímos no entrelaçamento do racional com o emocional, na linguagem, ou seja, é na linguagem que nos tornamos humanos e assumimos nossa condição biológica, ética e política, ao potencializarmos a emoção do amor na aceitação do outro como legítimo outro, na relação de convivência, no conversar. Para esse autor a razão é um domínio de ação fundante da emoção, diluindo assim, a dicotomia entre razão/emoção.

É no domínio da relação com o outro na linguagem que sucede o viver humano, e é, portanto, no âmbito ou domínio da relação com o outro que tem lugar a responsabilidade e a liberdade como formas de conviver (MATURANA; VARELA, 1997, p. 33).

No compartilhar a feitura dos mascarados do congo deparamos com processos de negociação e saberesfazeres socioambientais destacados nas conversas com a congueira e filha do mestre de congo. 
O João Bananeira surgiu aqui na região de Taquaruçu. Tinha um senhor que o nome dele era João e quando tinha a festa de congo ele se vestia de palhas de bananeira. A máscara surgiu através dos escravos que fugiam de Queimados/Serra e para não serem achados pelos seus patrões colocavam uma máscara para não serem reconhecidos e vinham para festa de Nossa Senhora da Penha com a máscara.

\section{Um jovem-congueiro, com-vive desde criança, com o devir-mascarado.}

Eu participo desde quando tinha seis anos, agora tenho quinze. Meu pai é filho do mestre. Hoje eu sou o casqueiro da banda de São Sebastião de Taquaruçu (que toca o instrumento casaca). Eles falam que é Zé Bananeira, João Bananeira, eu não sei direito. Eu sei que esse negócio eles inventaram.

Invenções cotidianas! Máscaras inventadas na cooperação e com o devir-mascarado! As vidas escapando aos controles, competições e da negação do amor. "A própria comunidade é quem as produz. Há meninos e meninas que sentem prazer em criar as suas máscaras.” (SANTOS, 2012, p.11).

Nós temos a biologia do compartilhar, e isso se nota na vida cotidiana. (...) $\mathrm{O}$ compartilhar é em nós um elemento que pertence à nossa biologia, não pertence à cultura. Pelo contrário, vivemos atualmente uma cultura que nega o compartilhar, porque estamos supostamente mergulhados na maravilha da competição (MATURANA, 2006, p. 93).

Nas redes de conversações com os sujeitos praticantes envolvidos com as feituras dos mascarados do congo vários sentidos e usos são criados nas artes de fazer e narrar, apesar das relações de controle, enredando resistências, sobrevivências e maneiras de fazer. O praticante do congo e escultor de máscaras, relata pontos de vistas observados a partir das experiências vividas com antigos congueiros da região.

As máscaras são produzidas com o molde de argila e posteriormente é coberto com papel. Depois a máscara é pintada. Como falei, a finalidade é esconder a identidade de quem a usa. Também são usados panos cobrindo a cabeça e meias nas mãos. São utilizados diversos materiais como sabugo de milho, fios, papel, etc., o que a criatividade mandar. (SANTOS, 2012, p.10-12).

As artes de fazer os mascarados do congo embalam os sujeitos praticantes em emoções amorosas, solidárias e cooperativas, produzindo aprendizagens inventivas autopoiéticas. Os caminhos propostos por Maturana revolucionam o modo como o discurso da ciência moderna 


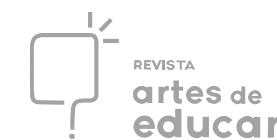

pensa a inteligência, na medida em que deixa de ser entendida como propriedade de alguém iluminado, como nos modelos tradicionais de educação, mas, como o que é produzido nas relações. As emoções, como o medo, a ambição, a competição, a violência, o preconceito restringe a inteligência. "O amor é a única emoção que amplia a inteligência" (MATURANA, 1999, p. 19).

As ideias de Maturana (2002) provocam um movimento de torcer nosso pensar as relações da Educação Ambiental autopoiética com redes de conversações cotidianas, com bases argumentativas que problematizam a ética e a política, diante dos modelos que veem a educação como mercadoria, pautada na concepção de aprendizagem apenas com uma roupagem utilitarista e produtivista, enfim, concebendo-a como um objetivo externo ou uma qualidade independente dos sujeitos envolvidos no processo.

Segundo Maturana (1999), "a ética não tem suas bases num operar racional, mas, sim, emocional". Ele também traz importantes pistas para pensarmos nossas práticas em Educação Ambiental, como educadores/as de maneira ética, colaborativa e mantendo nossa condição de sermos seres em constante processo de produção, seres autopoiéticos.

Ressalto também trechos da conversa com educando-morador da região:

Nessas máscaras você pega a argila, faz a forma que você quer e você enche de jornal, deixar secar, depois pinta e já está pronto! É fácil! Olha, eu faço porque eu ajudo o meu pai, porque ele é Presidente da Associação das Bandas. No carnaval eles colocam a máscara, ai não dá pra ninguém perceber. Um monte de gente faz máscaras. Tem criança e adolescente também. Eles fazem com palha de bananeira, colocam a máscara e fazem a roupa de palha de bananeira. Algumas pessoas vão com roupa normal. Eles usam uma linha e vão amarrando as palhas de bananeira, aí faz tipo uma saia. Eu gosto!

Como surgiram os mascarados do congo? Como foi inventado o "João (ou Zé) Bananeira" e suas máscaras e vestimentas? Como são feitas as máscaras? E as vestimentas? Quais os sentidos das máscaras? Quais as influências do território e da vida rural sobre as artes de fazer e narrar os mascarados do congo? Como as APA's da região povoam os imaginários e as práticas culturais cotidianas das comunidades?

Essas problematizações são inquietudes que deslocam os nossos pensamentos por redes de conversações cotidianas, que pretendem ir além das ideias aqui apresentadas. Nos encontros compartilhados com educadores/as em diferentes espaços de convivências, recorremos ao "diário de campo", com desejos de captar e acompanhar o congo de máscaras. A seguir, alguns lampejos desses atravessamentos com os diferentes espaços de convivências. 
Fios de conversas com dois praticantes do carnaval dos mascarados do congo, professores e ativistas culturais e que trazem à cena os mascarados. Aqui o mascarado é batizado como "Zé Bananeira":

Professor A: O nome toda vida foi Zé Bananeira, é de máscaras é claro, mas a gente sempre ouviu falar carnaval de congo. Então quando chegamos ao Carnaval de Congo de 1988, ficamos encantados, era coisa bem simples, roupas sujas, eles saiam de dentro mato, hoje as coisas ficaram bem diferentes, eles iam pra dentro do mato horas antes pra se arrumarem pra ninguém ver quem era. Tem o personagem João Bananeira e tem os Mascarados. Tem esses personagens que usam roupas sujas e têm os que se vestem de folhas de bananeira.

Professor B: O personagem do Zé Bananeira foi um personagem criado. Então, vimos aquilo tudo, fizemos uma caminhada de $10 \mathrm{~km}$ e eles bebiam cachaça, tocavam tambor até na casa, era muito longe, íamos à escuridão. Começamos a frequentar a região e conhecemos o senhor Queiroz que fazia as máscaras na época. Seu Queiroz resgatou o Carnaval de Congo e nós pegamos o básico do básico. Nós encontramos seu Queiroz e ele nos recebeu muito bem e começou a mostrar como fazia as máscaras.

Conversas tecidas com professores nos devires-mascarados traduzem relaçõesaproximações dos sujeitos praticantes do congo dos mascarados com as matas da região:

Professor C: A máscara era bem primitiva juntava o barro e fazia um molde, pegava jornal, papelão, revista, não usa cola tenaz, ele fazia goma de maisena, porque a intenção dele era fazer só pra festa daquele dia. Começava a fazer dez formas de barro, aí ele juntava o povo e ensinava a fazer a papietagem, tira de jornal e goma e depois tira de jornal nesta disposição. Tem gente que confunde papietagem com papel machê. O papel machê é o papel triturado, você faz a massa e a papietagem você faz tiras de papel sobrepostas até ficar uma camada espessa para depois retirar e pintar. Triturava também para fazer um nariz, uma orelha.

Professor D: Durante um tempo, esses mascarados começaram a fazer coisas do cotidiano junto com o Carnaval de Congo e foi se dimensionando. São várias versões do surgimento das máscaras, mas eu prefiro ouvir a do seu Queiroz. Ele falou que quando acabou a escravidão, a coisa de perseguição dos negros e eles 
foram se juntando e aí passou a ser muito mais uma coisa dos negros, mas isso tudo era a ocultação da identidade do negro no evento.

O congo dos mascarados como uma subversão, um escape! Táticas dos sujeitos praticantes e produtores desconhecidos, que inventam maneiras de fazer e burlar as formas-forças dos cotidianos... sujeitos não alienados! Aprendemos com Certeau (2008a) que "não devemos tomar o outro como idiotas", pensando em redes de astúcias, maneiras e artes de fazer e narrar, que subvertem, traçam desvios sutis e criações anônimas irrompendo a vida cotidiana, que não se capitaliza (FERRAÇO, 2003).

As conversas tecidas com educadores no decorrer dos encontros e experiências envolvendo a produção dos mascarados do congo, moveram-nos a pensar: como os saberesfazeres entrelaçados pelos sujeitos praticantes atravessam as redes cotidianas escolares e os outros espaços de convivências? Essas questões são provocações. Como dispositivo, destacamos a seguinte conversação com as artes de fazer dos mascarados e seus atravessamentos com os cotidianos escolares da região.

Professor A: A questão da escola com as bandas de congo é pela valorização da cultura, para aluno conhecer as manifestações folclóricas locais. Todo ano eu faço trabalho em escola, a gente faz oficinas de máscara, resgates. Eu fiz os moldes em papel com base no que seu Queiroz me ensinou.

Professor B: A gente começou a criar essa referência do Carnaval de Congo na escola. Eu comecei a trabalhar com professores, comecei a pegar a técnica. As crianças adoram, é instigante, colorido. Eu fiz um Baile de Máscara em homenagem ao Carnaval de Congo. Começamos a fazer as máscaras e os professores fizeram uma Oficina com alunos para fazerem as máscaras tradicionais com o pano e as crianças na sala fizeram as máscaras simples de cartolina. Todas as salas foram para o Carnaval de Congo e criamos um grupo vestidos de congo e com a máscara de Congo. A gente conta sobre as brincadeiras da máscara, o porquê esconder das máscaras. Trabalhei o Carnaval de Congo, as histórias, fiz a máscara, ensino a produção de máscaras, cada um produz a sua, eu não uso mais goma de trigo e sim, cola tenaz. Aí a criança hoje dentro da escola já conhece o Carnaval de Congo. Teve um dia que uma professora criou um painel maravilhoso da banana e se acoplou ao Carnaval de 
Congo por causa disso, e pendurou as máscaras. Então, começou a criar atividade.

As conversações da pesquisa foram tecidas nos entres das redes cotidianas em diferentes espaços de convivência, indicadas pelos rastros dos mascarados do congo em movimentos com os saberesfazeres, e que foram pistas potentes nessa produção de dados. Compartilhamos sorrisos, sons, cheiros, cores, sabores, saberes, amores, tensões, conflitos, paixões alegres, paixões tristes, afetos, e usos, do que aprendemos com as artes de viver e de conhecer.

Aprendemos também com Certeau (2008a, p. 152), que "se a própria arte de dizer é uma arte de fazer e de pensar, pode ser ao mesmo tempo a prática e a teoria dessa arte"...assim, as aprendizagens inventivas cotidianas e as experiências de vida podem ser encarnadas em processos cognitivos nos espaços escolares, em práticas de Educações Ambientais autopoiéticas, desprendendo-se dos sentidos das meras práticas eventuais, ao evidenciar a sua inventividade, a criação, a autoprodução e o autofazimento dos sujeitos praticantes dos cotidianos escolares e em outros espaços de convivências.

\section{Travessias sem fim dos mascarados: os sons, tons e cores.}

As máscaras em um trabalho inconcluso! Potencial criador e problematizador que acompanham as máscaras, os mascarados, os espíritos-santos-mascarados. As máscaras nas práticas culturais capixabas e seus saberesfazeres socioambientais na atualidade, nos cotidianos escolares e nos espaços de convivências. $\mathrm{O}$ que podem as máscaras? O que pode um cartógrafo nos cotidianos das Educações Ambientais? O que pode os Carnavais dos Amores? (RAMOS, p. 117, 2013)

Esse artigo desejou ser um exercício-movimento-deslocamento coletivo de discussão dos possíveis produzidos com as artes de fazer e narrar a produção dos mascarados do congo, cartografando e problematizando os saberesfazeres socioambientais nas redes de conversações cotidianas escolares e de outros espaços de convivências.

A aposta com a Educação Ambiental autopoiética está nas relações de aceitação do outro como legítimo outro na convivência, nas conversas, no fazer com, uma VIDA de menos competição e mais colaboração, culturas de solidariedade e respeito às formas de vida. $\mathrm{O}$ texto desmascara pistas que potencializam dimensões éticas, políticas, estéticas e as práticas cotidianas de sustentabilidades e de sustentabilizar as relações e experiências na vida cotidiana. 
Acreditamos que nossas vidas são constituídas de emaranhados de fios, fluxos, mãos, forças, corpos e de movimentos que compõem tons, dobras, sons, cores, cheiros, energias, na provisoriedade, que vibram e nos atravessam alargando e ventilando os possíveis, num devir cotidiano, num movimento de rasurar, rachar as coisas, rachar as palavras e de jamais interpretar... (DELEUZE, 1992), experimentando as dobras e redobras dos saberesfazeres socioambientais tecidos com redes de conversações cotidianas.

Acreditar no mundo é o que mais nos falta; nós perdemos completamente o mundo, nos desapossaram dele. Acreditar no mundo significa principalmente suscitar acontecimentos, mesmo pequenos, que escapem ao controle, ou engendrar novos espaços-tempos, mesmo de superfície ou volume reduzidos. (...) É ao nível de cada tentativa que se avaliam a capacidade de resistência ou, ao contrário, a submissão a um controle (DELEUZE, 1992, p.218).

A tentativa foi traçar linhas nas redes de conversações com a produção dos mascarados do congo, a pesquisa apostou na vida, nas experiências cooperativas, amorosas e felizes, conexões, fluxos, encontros intensos, cartografias, conversas, verdades inacabadas e aproximadas. E as conversas continuam... "O mundo é uma escola, a vida é um circo, amor, palavra que liberta já dizia o profeta" Gentileza (MONTE, 2000).

Atualmente a pesquisa com as máscaras de congo de Roda D’Água, continua sendo desenvolvida pela autora do artigo, com o ingresso no doutorado do Programa de Pós-Graduação em Educação da Universidade de Sorocaba (Uniso/SP). O desejo é continuar potencializando experiências em diferentes espaços de convivências, formação e de aprendizagens inventivas, dialogando com políticas cognitivas, epistemológicas e de narratividade, principalmente apostando nas dimensões políticas, ambientais e pedagógicas dos que vêm das margens (REIGOTA, 2013) e, com inspirações nas contribuições éticas, estéticas e políticas, presentes no pensamento de Paulo Freire (FREIRE, 2009) no campo da Educação Ambiental.

\section{REFERÊNCIAS}

ALVES, N. Sobre as razões das pesquisas nos/dos/com os cotidianos. In: GARCIA, L. R. (Org.) Diálogos cotidianos. Petrópolis, RJ: DP et al, Rio de Janeiro: FAPERJ, 2010.

BRASIL, Lei nº10.639 de 9 de janeiro de 2003. Ministério da Educação. Diretrizes Curriculares Nacionais para a Educação das Relações Étnicos Raciais e para o Ensino de História e Cultura Afro-Brasileira e Africana. MEC/SECAD. 2005. 
BRASIL. Lei 11.645, de 10 de marco de 2008. Disponível em:http://www.planalto.gov.br/ccivil_03/_ato2007-2010/2008/lei/111645.htm. Acesso em: 11 nov. 2014.

ASSMANN, H. Reencantar a educação: rumo à sociedade aprendente. 2. ed. Petrópolis: Vozes, 1998.

CARVALHO, J. M. A razão e os afetos na potencialização de "Bons encontros" no currículo escolar: Experiências cotidianas. In FERRAÇO, C. E. Currículo e Educação Básica: Por entre redes de conhecimentos, imagens, narrativas, experiências e devires. Rio de Janeiro: Rovelle, 2011.

CERTEAU, M. A invenção do cotidiano - artes de fazer. Petrópolis: Vozes, 2008a.

CERTEAU, M. A. Cultura no Plural. Campinas, SP: Papirus, 2008 b.

DELEUZE, G. Conversações. São Paulo: Ed.34. 1992.

DELEUZE, G.; GUATTARI, F. O que é a filosofia? Rio de Janeiro: Ed. 34, 1992.

DELEUZE, G.; GUATTARI, F. Mil Platôs. Volume 1. São Paulo: Ed. 34, 2011.

FERRAÇO, C. E. Eu, caçador de mim. In: GARCIA, R. L. (org.). Método: pesquisa com o cotidiano. Rio de Janeiro: DP\&A, 2003. p. 157-175.

FREITAS, D. O Carnaval de Congo de Roda d'Água - Cariacica - ES - Brasil. Dissertação de Mestrado/ Universidade de São Marcos. São Paulo/SP: 2007.

GONZALEZ, S. Educação Ambiental Autopoiética com as práticas do bairro Ilha das Caieiras entre os manguezais e as escolas. 2013. 159 f. Tese (Doutorado em Educação) - Programa de PósGraduação em Educação, Universidade Federal do Espírito Santo, Vitória, 2013.

GONZALEZ, S; RAMOS, A. T. Educação ambiental numa perspectiva autopoiética na formação de educadores/as. Pró-Discente: caderno de produções acadêmicas-científicas do Programa de Pós-Graduação em Educação. Universidade Federal do Espírito Santo, v. 18, n. 2, jul./dez., Vitória, ES, 2012.

. Educação ambiental Autopoiética na vida cotidiana. Textura. Canoas/RS. v.16. n. 30. Jan/abr. 2014. p.86-106.

KASTRUP, V. A invenção de si e do mundo: Uma introdução do tempo e do coletivo no estudo da cognição. Rio de Janeiro: Editora Autêntica, 2009.

LARROSA, J. Experiência e paixão. In: LARROSA, J. Linguagem e educação depois de Babel. Belo Horizonte: Autentica 2004.

MATURANA, H. A ontologia da realidade. Belo Horizonte: Editora da UFMG, 1999. . Emoções e linguagens na educação e na política. Belo Horizonte: UFMG, 2002. 
. Cognição, ciência e vida cotidiana. Belo Horizonte: UFMG, 2006.

MATURANA, H.; VARELA, F. A árvore do conhecimento. Campinas/SP: Psy, 1995.

. De máquinas e seres vivos. Autopoiese - a organização do vivo. Porto Alegre: Artes

Médicas, 1997.

MATURANA, H. G.VERDEN-ZOLLER, G. Amar e brincar: fundamentos esquecidos do humano do patriarcado à democracia. São Paulo: Palas Athena, 2004.

MATURANA, H. XIMENA, D. Y. Habitar Humano em seis ensaios de biologia cultural. São Paulo: Palas Athena, 2009.

MAZOCO, E. O congo de Máscaras. Vitória: Universidade Federal do Espírito Santo/Secretaria de Produção e Difusão Cultural, 1986.

MONTE, M. Gentileza. Memórias, Crônicas e declarações de amor. Rio de Janeiro: EMI, 2000.

NEVES, G. S. Coletânea de estudos e registros do folclore capixaba: 1944-1982. Vitoria: Centro

Cultural de Estudos e Pesquisas do Espírito Santo, 2008.

PASSOS, E.; KASTRUP, V.; ESCÓSSIA, L. Pistas do método da cartografia: pesquisaintervenção e produção de subjetividade. Porto Alegre: Sulina, 2010.

PELLANDA, N. Maturana e a Educação. Belo Horizonte: Pensadores \& a Educação. Ed. Autêntica, 2009.

RAMOS, T. A. Educação ambiental entre os carnavais dos amores com os mascarados do congo de Roda D’Água. 2013. 142 f. Dissertação (Mestrado em Educação) Universidade Federal do Espírito Santo, Vitória/ES, 2013.

REIGOTA, M. A contribuição política e pedagógica dos que vêm das margens. Teias. Rio de Janeiro: ano $11, \quad \mathrm{n}^{\mathrm{o}}$ 21, jan/abr 2010. Disponível em: $<\mathrm{http}$ ://periodicos.proped.pro.br/index.php/revistateias/article/viewFile/533/446, acesso em: 31 jul. 2013.

REVEL, J. Foucault: conceitos essenciais. São Carlos: Claraluz, 2005.

SANTOS, Z, F. O Carnaval de Congo de Roda D’Água. Guia Moxuara, Cariacica, 2012, ano I, edição I, p.28-29. Entrevista concedida a Revista Guia Moxuara pelo Zuilton Ferreira dos Santos. SEQUEIRA, P. F A.; de. Esboço histórico dos costumes do povo espírito-santense. Rio, 1893. 2. ed. 1944.

SOUZA, E. P. Tamborizar: História e afirmação da Auto-estima das crianças e adolescentes negros e negras através dos tambores de Congo. Dissertação de mestrado em educação. Salvador. UFB. 2005. 


\title{
TRISTÃO, M. Uma abordagem filosófica da pesquisa em Educação Ambiental. Revista Brasileira
}

\author{
de Educação v. 18 n. 55 out.- dez. 2013.
}

\footnotetext{
i Estudante e pesquisadora do curso de doutorado do Programa de Pós-Graduação em Educação (Uniso/SP). Agência de fomento CAPES

ii Professora Associada do Centro de Educação da UFES, atuando na graduação e na pós-graduação. Coordenadora do Núcleo Interdisciplinar de Pesquisas e Estudos em Educação Ambiental- NIPEEA

iii Ressalto que um fragmento desse texto foi apresentado na $36^{\circ}$ Reunião Anual da Associação de Pós-Graduação e pesquisa em educação (Anped), como comunicação oral no Grupo de Trabalho 22 (GT 22) Educação Ambiental, evento realizado na Universidade de Goiás em outubro de 2013.

${ }^{\text {iv }}$ Revel (2005, p. 71) destaca que "o termo problematização implica duas consequências. De um lado, o verdadeiro exercício crítico do pensamento se opõe à ideia de uma busca metódica da "solução": a tarefa da fillosofia não é, portanto, a de resolver - inclua-se: substituir uma solução por uma outra - mas a de "problematizar", instaurando uma postura crítica e retomando os problemas. De outro lado, esse esforço de problematização não é um anti-reformismo ou um pessimismo relativista.

" Revel (2005, p. 21) destaca que “Atualidade” e "presente" são, inicialmente, sinônimos. No entanto, uma diferença vai se acentuar cada vez mais entre o que, de um lado, nos precede, mas continua, apesar de tudo, a nos atravessar e o que, de outro lado, sobrevém, ao contrário, como uma ruptura da grade epistêmica a que pertencemos e de periodização que ela engendra. Essa irrupção do "novo", que tanto Foucault quanto Deleuze chamam igualmente de "acontecimento", torna-se, assim, o que caracteriza a atualidade.

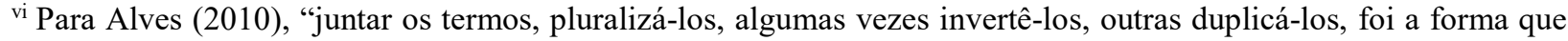
conseguimos, até o presente, para mostrar como as dicotomias necessárias na invenção da ciência moderna têm se mostrado limitantes ao que precisamos criar para pesquisar nos/dos/com os cotidianos".

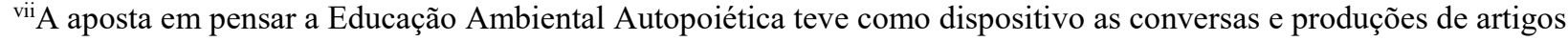
envolvendo obras de Maturana e as suas parcerias com Varela (1995 e 1997), Verden-Zoller (2004) e Yáñez (2009), sendo que os estudos desses trabalhos, inspiraram produções de pesquisas em parceria com um professor adjunto de uma universidade federal, e que resultaram na dissertação de mestrado (RAMOS, 2013), tese de doutorado em educação (GONZALEZ, 2013) e outros artigos publicados em eventos acadêmicos (GONZALEZ e RAMOS, 2012 e 2014).

viii Ressalto que a pesquisa, quando pousou no cotidiano da escola campo, considerou os desafios de pensar as relações étnicos-raciais, a população negra, afrodescendente e indígenas, que são também sujeitos praticantes do congo de máscaras, apostando na formação de professores/as, com aportes éticos, estéticos e políticos. Considerando as garantias de direito previstas na legislação educacional do Brasil que, em janeiro 2003, criou a Lei 10.639/03 (2005), que determina como obrigatório o Ensino sobre a História e Cultura Afro-Brasileira nas escolas públicas e privadas. Em março de 2008, a 11.645/08 (2008) alterou a lei anterior e acrescentava como temática para a educação nacional a história e cultura indígena.

${ }^{\text {ix }}$ Os sujeitos praticantes para Certeau (2008b) são sujeitos que inventam e reinventam os mundos nos cotidianos, nas artes de fazer com os usos de táticas e estratégias de resistências, se reapropriando, a seu jeito, do espaço e do uso do lugar praticado.

${ }^{x}$ Neste texto apenas alguns lampejos dos registros de conversações serão apresentados, considerando que devido ao limite do artigo não é possível colocar todas as transcrições. As conversações foram gravadas, transcritas e problematizadas de acordo com os objetivos da pesquisa, compondo o que chamamos de "diário de campo".

xi Pensamos a noção de experiência com inspirações em Larrosa (2004, p. 154), "experiência é o que nos passa, ou o que nos acontece, ou nos toca. (...) A cada dia passam muitas coisas, porém, ao mesmo tempo, quase nada nos passa. Dir-se-ia que tudo está organizado para que nada no passe".
} 